\author{
K.M. Turdybekov ${ }^{1 *}$, Zh.S. Nurmaganbetov ${ }^{2}$, D.M. Turdybekov ${ }^{3}$, \\ G.K. Mukusheva ${ }^{1}$, Yu.V. Gatilov ${ }^{4}$ \\ ${ }^{1}$ Karagandy University of the name of academician E.A. Buketov, Kazakhstan; \\ ${ }^{2}$ Karaganda Medical University, Kazakhstan; \\ ${ }^{3}$ Karaganda Technical University, Kazakhstan \\ ${ }^{4}$ N.N. Vorozhtsov Novosibirsk Institute of Organic Chemistry, Russia \\ (Corresponding author's e-mail: xray-phyto@yandex.kz)
}

\title{
Synthesis, molecular and crystalline structure of 8-formylharmine
}

\begin{abstract}
For the first time, synthesis of 8-formylharmine by the Vilsmeier reaction was carried out. 8-Formylharmine was obtained by treating alkaloid harmine with dichloromethoxymethane in the presence of $\mathrm{SnCl}_{4}$. The yield of the target product was $64 \%$. The structure of the obtained compound was established on the basis of ${ }^{1} \mathrm{H}$ and ${ }^{13} \mathrm{C}$ NMR spectroscopy as well as mass-spectrometry data. The crystalline structure of 8 -formylharmine was determined by X-ray diffraction. It has been shown that the replacement of the hydrogen atom in the harmine molecule with a formyl group occurs at the C8 atom. It was revealed that the methoxy group at the C7 atom changes its orientation to the opposite one as compared to the orientation in the harmine molecule and its salts due to the mutual Van der Waals repulsion of the methoxy and formyl groups. A weak intramolecular hydrogen bond was found in the crystal between the $\mathrm{O} 2$ atom of the formyl group and the hydrogen atom of the secondary amino group. It was shown that molecules in the crystal form an intermolecular hydrogen bond between the same atoms (O2 and HN9A), as a result of which dimers are formed.
\end{abstract}

Keywords: NMR spectroscopy, mass- spectrometry, X-ray diffraction analysis, crystal structure, hydrogen bond, harmine, 8 -formylharmine, harmine derivatives.

\section{Introduction}

$\beta$-Carboline fragments of heterocycles of natural origin are part of many indole alkaloids, showing valuable pharmacological properties. Known examples of compounds comprising $\beta$-carboline fragment and exhibiting antimalarial and cytotoxic effect on certain types of tumor cells, as well as of great interest as promising compounds that are leaders in the search for new physiologically active agents to treat diseases of the central nervous system and cardiovascular system $[1,2]$.

According to the literature, among indole alkaloids, $\beta$-carbolines are much less studied, and some of them are unknown at all. At the same time, compounds of this class have a significant potential for medical chemistry and pharmacology, since it can be assumed that they have a combination of biological properties characteristic of isomeric carbolins.

The alkaloid of the $\beta$-carboline type harmine (1) is contained in the plant Peganum harmala L., which is widespread in the Republic of Kazakhstan. Harmine has a diverse biological activity: antitumor [3], antiviral [4] and anti-inflammatory [5]. Harmine has an effect on the central nervous system, exhibiting neuroprotective activity in neurological diseases [6], and inhibits monoamine oxidase A [7].

In continuation of our studies on the conversions of the harmine alkaloid, the synthesis of a harmine derivative containing a different substituent at position $\mathrm{C} 8$ was carried out [8]. It should be noted that modifications at the $\mathrm{C} 8$ atom are of interest in connection with the valuable antitumor and antimicrobial activity of synthetic and natural 8-halogen-substituted [9] and 8-methylamino-substituted [10] $\beta$-carbolines described in the literature.

\section{Experimental}

The ${ }^{1} \mathrm{H}$ and ${ }^{13} \mathrm{C}$ NMR spectra of compound (2), dissolved in $\mathrm{CDCl}_{3}+\mathrm{CD}_{3} \mathrm{OD}$, were recorded on a Bruker AV-600 spectrometer (operating frequencies $600.30\left({ }^{1} \mathrm{H}\right)$ and $150.96 \mathrm{MHz}\left({ }^{13} \mathrm{C}\right)$ relative to $\mathrm{SiMe}_{4}$. Various types of proton-proton and carbon-proton shear correlation spectroscopy (COSY, COXH, COLOC) were used for the assignment of signals in the NMR spectra. Multiplicity of signals in ${ }^{13} \mathrm{C}$ NMR spectra was determined by recording the spectra in J-modulation mode. High-resolution mass spectra were recorded on a

${ }^{*}$ Corresponding author. 
DFS Thermo Scientific mass spectrometer, evaporator temperature $150-240{ }^{\circ} \mathrm{C}$, ionization of ES $(70 \mathrm{eV})$. Elemental analysis was performed on the Eurovector 3000 analyzer.

Melting point was determined on an SMF-38 heating table. The reaction progress was monitored by TLC on Silufol UV-254 plates. The spots were developed by spraying the plates with a $10 \%$ aqueous solution of $\mathrm{H}_{2} \mathrm{SO}_{4}$, followed by heating to $100{ }^{\circ} \mathrm{C}$ or by irradiation with ultraviolet radiation. The reaction product was isolated by column chromatography on silica gel ("Acros", $0.035-0.070 \mathrm{~mm}$, pore diameter $6 \mathrm{~nm}$ ), eluent: chloroform-ethyl acetate.

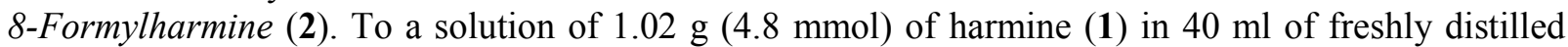
$\mathrm{CHCl}_{3}$ cooled to $0{ }^{\circ} \mathrm{C}, 1.21 \mathrm{~g}(10.5 \mathrm{mmol})$ of $\mathrm{Cl}_{2} \mathrm{CHOCH}_{3}$ and $0.81 \mathrm{~g}(3.1 \mathrm{mmol})$ of $\mathrm{SnCl}_{4}$ were added with stirring. The reaction mixture was stirred for 2 hours at $0{ }^{\circ} \mathrm{C}$, then 20 hours at room temperature, and then poured onto ice. The mixture was treated with $5 \%$ aqueous ammonia (to $\mathrm{pH} 9$ ) and extracted with chloroform $(3 \times 30 \mathrm{ml})$. The organic extracts were combined, washed with saturated $\mathrm{NaCl}(15 \mathrm{ml})$ and dried over $\mathrm{MgSO}_{4}$. The desiccant is filtered off, the solvent is evaporated off under reduced pressure. The residue was chromatographed on an alumina column (eluent is chloroform — EtOAc, gradient from 100:1 to 10:1). The fraction containing the product was recrystallized from a mixture of chloroform-petroleum ether, 5:1. Yield is $312 \mathrm{mg}(64 \%)$, yellow fine-crystalline powder, $\mathrm{mp} .112-115^{\circ} \mathrm{C}$.

NMR spectrum ${ }^{1} \mathrm{H}\left(\mathrm{CDCl}_{3}+\mathrm{CD}_{3} \mathrm{OD}\right), \delta$, ppm. $(J, \Gamma ц): 2.71\left(3 \mathrm{H}, \mathrm{s}, \mathrm{CH}_{3}\right.$ at $\left.\mathrm{C}-1\right) ; 3.95\left(3 \mathrm{H}, \mathrm{s}, \mathrm{OCH}_{3}\right)$; $6.79(1 \mathrm{H}, \mathrm{d}, J=8.7,6-\mathrm{CH}) ; 7.62(1 \mathrm{H}, \mathrm{d}, J=5.5,4-\mathrm{CH}) ; 8.13(1 \mathrm{H}, \mathrm{d}, J=8.7,5-\mathrm{CH}) ; 8.16(1 \mathrm{H}, \mathrm{d}, J=5.5$, 3-CH); $10.75\left(1 \mathrm{H}\right.$, br.s, CHO). NMR spectrum ${ }^{13} \mathrm{C},\left(\mathrm{CDCl}_{3}+\mathrm{CD}_{3} \mathrm{OD}\right), \delta$, ppm.: $19.25\left(1-\mathrm{CH}_{3}\right) ; 56.17$ $\left(\mathrm{OCH}_{3}\right) ; 103.70(\mathrm{C}-6) ; 108.55$ (C-8); 112.12 (C-4); 116.24 (C-4a); 127.42 (C-4b); 130.25 (C-5); 134.62 (C-9a); $140.06(\mathrm{C}-3) ; 141.52,141.78(\mathrm{C}-1,8 \mathrm{a}) ; 163.50(\mathrm{C}-7) ; 190.58(\mathrm{C}=\mathrm{O})$. Mass spectrum, $\mathrm{m} / z\left(I_{\text {отн }} \%\right)$ : 241 (14), 240 (100), 239 (7), 225 (6), 194 (15), 169 (18), 18 (12). Found, $m / z: 240.0890[\mathrm{M}]^{+} . \mathrm{C}_{14} \mathrm{H}_{12} \mathrm{~N}_{2} \mathrm{O}_{2}$. Calculated, $m / z$ : 240.0893. Found, \%: C 69.71; H 5.12; N 11.49. $\mathrm{C}_{14} \mathrm{H}_{12} \mathrm{~N}_{2} \mathrm{O}_{2}$. Calculated, \%: C 69.99; H 5.03; N 11.66 .

$X$-ray analysis of compound (2). The cell parameters and the intensity of 10235 reflections (2001 independent, $\left.\mathrm{R}_{\text {int }}=0.0601\right)$ were measured on a diffractometer "Bruker Kappa APEX2 CCD" (MoK ${ }_{\alpha}$, graphite monochromator, $\varphi, \theta$-scan, $1.81 \leq \theta \leq 25.05)$ at $296 \mathrm{~K}$. The crystals are monoclinic, $\mathrm{a}=11.539(2)$, $\mathrm{b}=5.0197(9), \mathrm{c}=20.198(4) \AA, \beta=103.077(8)^{\circ}, \mathrm{V}=1139.6(4) \AA^{3}, \mathrm{Z}=4\left(\mathrm{C}_{14} \mathrm{H}_{12} \mathrm{~N}_{2} \mathrm{O}_{2}\right)$, The space group $P 2_{l} / c$, $\mathrm{d}_{\text {calc }}=1.400 \mathrm{~g} / \mathrm{cm}^{3}, \mu=0.096 \mathrm{~mm}^{-1}$. The initial array of the measured intensities was processed and absorption was taken into account using the SAINT [11] and SADABS [12] programs (multi-scan, $\mathrm{T}_{\min }=0.9700$, $\mathrm{T}_{\max }=0.9986$ ).

The structure of compound (2) is deciphered by a direct method. The positions of non-hydrogen atoms are refined in the anisotropic approximation by the full-matrix least squares. Hydrogen atom at N9A is revealed from the difference synthesis and its position is refined in the isotropic approximation. The remaining hydrogen atoms were placed in geometrically calculated positions and positions were refined in an isotropic approximation with fixed positional and thermal parameters (the "rider" model). The structure is deciphered and refined by the complex of programs SHELXS [13] and SHELXL-2018/3 [14]. 1319 independent reflections used for calculations with $I \geq 2 \sigma(\mathrm{I})\left(\mathrm{R}_{\text {int }}=0.0601\right)$, the number of parameters to be refined 169 . The final divergence factors $R_{1}=0.0428,{ }_{\mathrm{w}} R_{2}=0.1100$ (for reflections with $I \geq 2 \sigma(I)$ ), $R_{I}=0.0880,{ }_{\mathrm{w}} R_{2}=0.1557$ (for all reflections), $G o o F=1.049$. Peaks of residual density: $\Delta \rho=0.283$ and $-0.283 \mathrm{e} / \AA^{3}$. The CIF file containing the complete information on the structure examined is deposited in the Cambridge Center for Crystal Structural Data (CCDC), under number 1854103. The atomic coordinates are shown in Table 1.

T a b l e 1

The coordinates of the atoms in the fractions of the cell $\left(\times 10^{4}\right.$, for $\left.\mathrm{H} \times 10^{3}\right)$ and isotropic thermal parameters $\left(\AA^{2}, \times 10^{3}\right)$ in the structure (2)

\begin{tabular}{|c|c|c|c|c|}
\hline Atom & $x$ & $y$ & $z$ & $\mathrm{U}_{\text {экв. }}$ \\
\hline 1 & 2 & 3 & 4 & 5 \\
\hline $\mathrm{O} 1$ & $13413(2)$ & $655(4)$ & $4336(1)$ & $52(1)$ \\
\hline $\mathrm{O} 2$ & $11107(2)$ & $-3934(4)$ & $4993(1)$ & $48(1)$ \\
\hline $\mathrm{C} 1$ & $7032(2)$ & $-1004(5)$ & $3561(1)$ & $38(1)$ \\
\hline $\mathrm{N} 2$ & $6199(2)$ & $286(4)$ & $3097(1)$ & $46(1)$ \\
\hline $\mathrm{C} 3$ & $6542(3)$ & $2191(6)$ & $2713(2)$ & $49(1)$ \\
\hline $\mathrm{C} 4$ & $7693(2)$ & $2979(5)$ & $2763(1)$ & $45(1)$ \\
\hline
\end{tabular}


Synthesis, molecular and crystalline structure ...

\begin{tabular}{|c|c|c|c|c|}
\multicolumn{5}{|c|}{ C o n t i n u a t i o n } \\
\hline 1 & 2 & 3 & 4 & 5 \\
\hline C4A & $8574(2)$ & $1681(5)$ & $3242(1)$ & $34(1)$ \\
\hline C4B & $9851(2)$ & $1876(5)$ & $3447(1)$ & $34(1)$ \\
\hline C5 & $10703(2)$ & $3441(5)$ & $3251(1)$ & $41(1)$ \\
\hline C6 & $11894(2)$ & $3086(5)$ & $3538(1)$ & $41(1)$ \\
\hline C7 & $12252(2)$ & $1134(5)$ & $4035(1)$ & $37(1)$ \\
\hline C8 & $11423(2)$ & $-494(5)$ & $4260(1)$ & $34(1)$ \\
\hline C9 & $10215(2)$ & $-94(4)$ & $3956(1)$ & $31(1)$ \\
\hline N9A & $9236(2)$ & $-1389(4)$ & $4064(1)$ & $35(1)$ \\
\hline C9B & $8224(2)$ & $-338(5)$ & $3632(1)$ & $33(1)$ \\
\hline C10 & $6617(2)$ & $-3085(6)$ & $3982(2)$ & $50(1)$ \\
\hline C11 & $14304(3)$ & $2328(7)$ & $4168(2)$ & $68(1)$ \\
\hline C12 & $11791(2)$ & $-2498(5)$ & $4783(1)$ & $41(1)$ \\
\hline H9A & $922(2)$ & $-258(6)$ & $431(2)$ & $49(1)$ \\
\hline
\end{tabular}

\section{Results and Discussions}

As a continuation of our research on the transformations of the harmine alkaloid (1) we synthesized a harmine derivative containing a different substituent in the C-8 position.

The introduction of a formyl group into the harmine (1) molecule by the Wilsmeier reaction leads to the formation of 8-formylharmine (2) with a yield of $64 \%$. We have proposed a method of producing 8 -formylhamine when interacting with harmine dichloromethoxymethane in the presence $\mathrm{SnCl}_{4}$.<smiles></smiles><smiles>COc1ccc2c3ccnc(C)c3n([TlH])c2c1C=O</smiles>

The structure of the obtained compound (2) was established on the basis of ${ }^{1} \mathrm{H}$ and ${ }^{13} \mathrm{C}$ NMR spectroscopy and mass-spectrometry. A peak with a molecular weight of $240.0890 \mathrm{Da}$ was found in the massspectrum of the obtained product, corresponding to the molecular ion $\mathrm{C}_{14} \mathrm{H}_{12} \mathrm{~N}_{2} \mathrm{O}_{2}{ }^{+}$(calculated: $240.0893 \mathrm{Da}$ ). When comparing the NMR spectra of compound (2) with the spectra of the original molecule (1), new signals were detected. The proton signal at $\mathrm{C} 8$ disappeared in the ${ }^{1} \mathrm{H}$ NMR spectrum and appeared at $10.75 \mathrm{ppm}$. $\left(1 \mathrm{H}\right.$, br.s), corresponding to the proton of the group $\mathrm{C}(\mathrm{H})=\mathrm{O}$, and in the ${ }^{13} \mathrm{C} N M R$ spectrum a signal of $190.58 \mathrm{ppm}$ corresponding to the carbon of the aldehyde group $(\mathrm{C}=\mathrm{O})$. The full assignment of NMR signals is given in the experimental part.

In order to confirm the place of replacement of the hydrogen atom by the formyl group and to continue studying the crystal structures of alkaloids, the structure of 8-formylharmine was studied (2), a general view of which is shown in Figure 1.

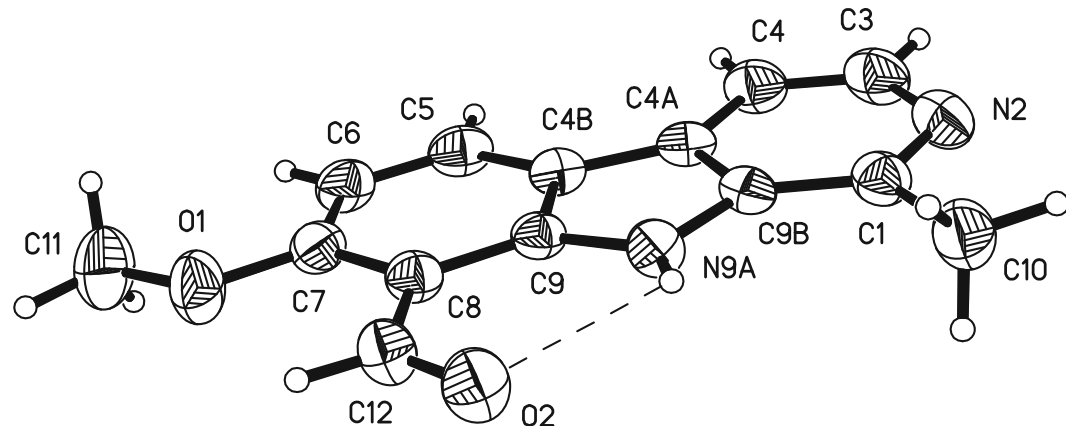

Figure 1. The structure of 8-formylharmine (thermal vibration ellipsoids shown with a probability of $50 \%$ ). The dashed line shows the hydrogen bond 
From the data obtained it follows that bond lengths (Table 2) and bond angles (Table 3) in compounds (2) are close to usual [15].

Table 2

Bond lengths (d, $\AA$ ) in the structure (2)

\begin{tabular}{|c|c|c|c|}
\hline Bond & $\mathrm{d}$ & Bond & $\mathrm{d}$ \\
\hline O1-C7 & $1.362(3)$ & C4A-C4B & $1.441(4)$ \\
\hline O1-C11 & $1.427(3)$ & C4B-C5 & $1.385(3)$ \\
\hline O2-C12 & $1.213(3)$ & C4B-C9 & $1.420(3)$ \\
\hline C1-N2 & $1.346(3)$ & C5-C6 & $1.376(4)$ \\
\hline C1-C9B & $1.391(4)$ & C6-C7 & $1.397(4)$ \\
\hline C1-C10 & $1.492(4)$ & C7-C8 & $1.409(3)$ \\
\hline N2-C3 & $1.346(4)$ & C8-C9 & $1.405(3)$ \\
\hline C3-C4 & $1.367(4)$ & C8-C12 & $1.452(4)$ \\
\hline C4-C4A & $1.396(4)$ & C9-N9A & $1.362(3)$ \\
\hline C4A-C9B & $1.399(3)$ & N9A-C9B & $1.394(3)$ \\
\hline
\end{tabular}

$\mathrm{Tab} l \mathrm{e} 3$

Valent angles $(\omega$, deg.) in the structure (2)

\begin{tabular}{|c|c|c|c|}
\hline Angle & $\omega$ & Angle & $\omega$ \\
\hline C7-O1-C11 & $118.6(2)$ & O1-C7-C6 & $123.1(2)$ \\
\hline N2-C1-C9B & $119.3(2)$ & O1-C7-C8 & $115.1(2)$ \\
\hline N2-C1-C10 & $117.5(2)$ & C6-C7-C8 & $121.8(2)$ \\
\hline C9B-C1-C10 & $123.1(2)$ & C9-C8-C7 & $117.1(2)$ \\
\hline C3-N2-C1 & $119.1(2)$ & C9-C8-C12 & $121.0(2)$ \\
\hline N2-C3-C4 & $124.8(3)$ & C7-C8-C12 & $121.9(2)$ \\
\hline C3-C4-C4A & $117.4(3)$ & N9A-C9-C8 & $129.7(2)$ \\
\hline C4-C4A-C9B & $118.0(2)$ & N9A-C9-C4B & $109.2(2)$ \\
\hline C4-C4A-C4B & $134.8(2)$ & C8-C9-C4B & $121.1(2)$ \\
\hline C9B-C4A-C4B & $107.1(2)$ & C9-N9A-C9B & $109.1(2)$ \\
\hline C5-C4B-C9 & $119.3(2)$ & C1-C9B-N9A & $130.0(2)$ \\
\hline C5-C4B-C4A & $134.6(2)$ & C1-C9B-C4A & $121.4(2)$ \\
\hline C9-C4B-C4A & $106.1(2)$ & N9A-C9B-C4A & $108.6(2)$ \\
\hline C6-C5-C4B & $120.8(2)$ & O2-C12-C8 & $124.0(2)$ \\
\hline C5-C6-C7 & $119.8(2)$ & & \\
\hline
\end{tabular}

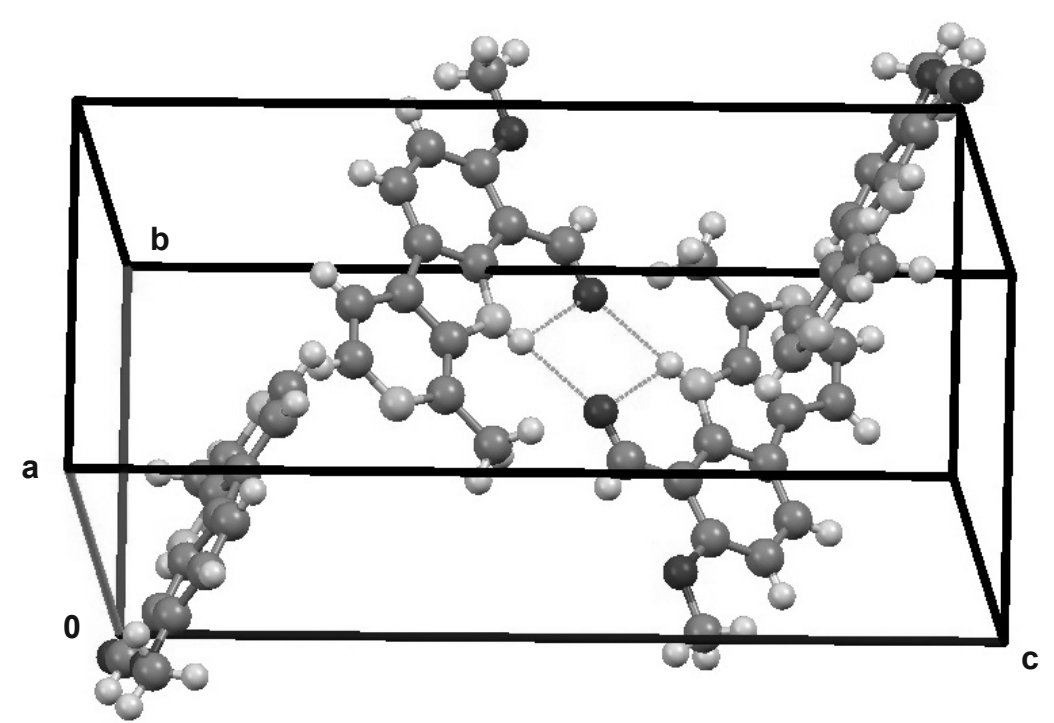

Figure 2. Packing of molecules (2) in a crystal lattice. Dotted lines show hydrogen bond 
Atoms of the main frame are in the same plane with an accuracy of \pm 0.01 Á. The methoxy group is located almost in its plane (torsion angle $\mathrm{C} 6 \mathrm{C} 7 \mathrm{O} 1 \mathrm{C} 11=3.9^{\circ}$ ), however, it is turned in the opposite direction, and the difference from the turn in the harmine molecule [16] is in the crystal hydrate of harmine hydrochloride [17] and harmine sulfate [18] (torsion angle C6C7O1C11 $=179.9^{\circ},-178.1^{\circ}$ and $176.4(-177.4)^{\circ}$ (two crystallographically independent molecules, respectively).

In the crystal, molecules (2) are connected by a weak intramolecular hydrogen bond N9A-H (x, y, z)... $\mathrm{O} 2$ (x, y, z) (distances N-H 0.78 (3) Á, N.... O 2.824 (3) Á, H.... O 2.40 (3) Á, angle N-H.... O $\left.116(3)^{\circ}\right)$. In addition, the intermolecular hydrogen bond N9A-H (x, y, z).... O2 (2-x, -1-y, 1-z) (distances N.... O 3.105 (3) $\AA$ Á, H.... O 2.33 (3) $\AA$, angle N-H....O $\left.172(3)^{\circ}\right)$, as a result of which the molecules form dimers (Figure. 2).

\section{Conclusions}

As a result of synthesis and study of the spatial structure of 8-formylharmine:

- the place of substitution of the hydrogen atom in the harmine molecule with the formyl group was determined;

- it was revealed that the methoxy group at the $\mathrm{C} 7$ atom changes its spatial orientation to the opposite in comparison with the orientation in harmine and its salts;

- a weak hydrogen bond was detected between the $\mathrm{O} 2$ atom of the formyl group and the hydrogen atom of the secondary amino group;

- it was shown that in a crystal the molecules form an intermolecular hydrogen bond between the same atoms, as a result of which they form dimers.

\section{References}

1 Moloudizargari M. Pharmacological and Therapeutic effects of Peganum harmala and its main alkaloids / M. Moloudizargari, P. Mikaili, S. Aghajanshakeri, M.H. Asghari, J. Shayegh // Pharmacognosy Rev. — 2013. — Vol. 7. — P. $199-205$.

2 Patel K. A review on medicinal importance, pharmacological activity and bioanalytical aspects of $\beta$-carboline alkaloid "Harmine" / K. Patel, M. Gadewar, R. Tripathi, S.K. Prasad, D.K. Patel // Asian Pac. J. Trop. Biomed. — 2012. — Vol. 2. — P. 660665.

3 Ishida J. Antitumor Agents 201 Cytotoxicity of Harmine and $\beta$-Carboline Analogs / J. Ishida, H.K. Wang, K.F. Bastow, C.Q. Hu, K.H. Lee // Bioorg. Med. Chem. Lett. — 1999. — Vol. 9. — P. 3319-3324.

4 Chen D. Harmine blocks herpes simplex virus infection through downregulating cellular NF-kappaB and MAPK pathways induced by oxidative stress / D. Chen, A. Su, Y. Fu, X. Wang, X. Lu, W. Xu, S. Xu, H. Wang, Z. Wu // Antivir. Res. - 2015. Vol. 123. - P. 27-38.

5 Zhao F. In vitro anti-inflammatory effects of $\beta$-carboline alkaloids, isolated from Picrasma quassioides, through inhibition of the iNOS pathway / F. Zhao, Z. Gao, W. Jiao, L. Chen, L. Chen, X. Yao // Planta Med. - 2012. — Vol. 78. — P. $1906-1911$.

6 Sun P. Harmine mediated neuroprotection via evaluation of glutamate transporter 1 in a rat model of global cerebral ischemia / P. Sun, S. Zhang, Y. Li, L. Wang // Neurosci. Lett. — 2014. — Vol. 583. — P. 32-36.

7 Kim H. Inhibition of monoamine oxidase A by $\beta$-Carboline derivatives / H. Kim, S.O. Sablin, R.R. Ramsay // Arch. Biochem. Biophys. — 1997. — Vol. 337. - P. 137-142.

8 Cao R. Synthesis and structure-activity relationships of asymmetric dimeric $\beta$-carboline derivatives as potential antitumor agents / R. Cao, W. Fan, L. Guo, Q. Ma, G. Zhang, J. Li, X. Chen, Z. Ren, L. Qiu // Eur. J. Med. Chem. — 2013. - Vol. 60. P. 10-22.

9 Zhang X.F. Synthesis and mechanisms of action of novel harmine derivatives as potential antitumor agents / X.F. Zhang, R. Sun, Y. Jia, Q. Chen, R.F. Tu, K. Li, X.D. Zhang, R.L. Du, R. Cao // Sci. Rep. — 2016. — Vol. 6. — P. 33204-33209.

10 Nurmaganbetov Zh.S. Synthesis of substituted indolizino[8,7-b]indoles from harmine and their biological activity / Zh.S. Nurmaganbetov, E.E. Shultz, S.V. Chernov, A.Zh. Turmukhambetov, R.B. Seydakhmetova, M.M. Shakirov, G.A. Tolstikov, S.M. Adekenov // Chem. Heterocycl. Comp. — 2011. - Vol. 46. - P. 1494-1499.

11 Bruker. SAINT. Bruker AXS Inc., Madison, Wisconsin, USA, 2015.

12 Bruker. SADABS. Bruker AXS Inc., Madison, Wisconsin, USA, 2015.

13 Sheldrick G.M. Crystal structure solution with SHELXS / G.M. Sheldrick // Acta Crystaollogr. Sect. A. — 2008. — Vol. 64. - P. 112-122.

14 Sheldrick G.M. Crystal structure refinement with SHELXL / G.M. Sheldrick // Acta Crystaollogr. Sect. C. — 2015. Vol. 71. - P. 3-8.

15 Allen F.H. Tables of bond lengths deternined by X-ray and neutron diffraction / F.H. Allen, O. Kennard, D.G. Watson, L. Brammer, A.G. Orpen, R. Taylor // J. Chem. Soc. Perkin. Trans. 2. - 1987. - P. 1-19. 
16 Maulik P.R. Harmine (7-methoxy-1-methyl-9H-pyrido[3,4-b]indole) / P.R. Maulik, B.S. Basak // Cryst. Struct. Commun. 1982. — Vol. 11. - P. 19-24.

17 Ferretti V. Structural features controlling the binding of beta-carbolines to the benzodiazepine receptor / V. Ferretti, P. Gilli, P.A. Borea // Acta Crystallogr. Sect. B: Struct. Sci. — 2004. — Vol. 60. — P. 481-489.

18 Turmukhambetov A.Zh. Synthesis of quaternary salts of Peganum harmala alkaloids / A.Zh. Turmukhambetov, M.T. Agedilova, Zh.S. Nurmaganbetov, A.V. Kazantsev, S.M. Adekenov, E.E. Shults, M.M. Shakirov, I.Yu. Bagryanskaya // Chem. Natur. Comp. - 2009. - Vol. 45. - P. 601-603.

\author{
Қ.М. Тұрдыбеков, Ж.С. Нұрмағанбетов, Д.М. Тұрдыбеков, \\ Г.К. Мұқышева, Ю.В. Гатилов
}

\title{
8-Формилгарминнің синтезі, молекулярлық және кристалдық құрылымы
}

\begin{abstract}
Алғаш рет Вильсмайер реакциясы арқылы 8-формилгарминнің синтезі жүзеге асырылды. 8Формилгармин туындысы гармин алкалоидын $\mathrm{SnCl}_{4}$ қатысында дихлорметоксиметанмен өңдеу арқылы синтезделді. Мақсатты өнімнің шығымы 64 \% құрайды. Синтезделген қосылыстың құрылысы ${ }^{1} \mathrm{H},{ }^{13} \mathrm{C}$ ЯМР спектроскопия және масс-спектрометрия әдістерімен дәлелденді. 8-Формилгарминнің кристалдық құрылымы рентген сәулелерінің дифракциясымен анықталды. Молекуладағы сутегі атомын гарминнің формил тобына алмастыру С8 атомында жүретіні көрсетілген. С7 атомындағы метокси тобы кеңістіктегі бағдарлануын, гармин мен оның тұздарындағы бағытқа қарағанда керісінше өзгертетінін байқатты. Бұл метокси- және формильді топтардың өзара ван-дер-ваальстік ығысуларынан пайда болады. Формил тобының О2 атомы мен екіншілік амин тобының сутегі атомы арасындағы кристалда ішкімолекулалық әлсіз сутектік байланысы байқалады. Кристалда молекулалар бірдей атомдар арасында молекулааралық сутектік байланысын (O2 и HN9A) құрайтыны және нәтижесінде олардың димер түзетіндігі көрсетілген.
\end{abstract}

Кілm сөздер: ЯМР-спектроскопия, масс-спектрометрия, рентгенқұрылымдық талдау, кристалдық құрылым, сутектік байланыс, гармин, 8-формилгармин, гарминнің туындысы.

\author{
К.М. Турдыбеков, Ж.С. Нурмаганбетов, Д.М. Турдыбеков, \\ Г.К. Мукушева, Ю.В. Гатилов
}

\section{Синтез, молекулярная и кристаллическая структура 8-формилгармина}

\begin{abstract}
Впервые осуществлен синтез 8-формилгармина по реакции Вильсмайера. 8-Формилгармин получили обработкой алкалоида гармина дихлорметоксиметаном в присутствии $\mathrm{SnCl}_{4}$. Выход целевого продукта составил $64 \%$. Строение полученного соединения установили на основании спектров ${ }^{1} \mathrm{H}$ и ${ }^{13} \mathrm{C}$ ЯМР-спектроскопии, а также данных масс-спектрометрии. Кристаллическую структуру 8-формилгармина определяли с помощью дифракции рентгеновских лучей. Показано, что замещение атома водорода в молекуле гармина на формильную группу происходит при атоме С8. Выявлено, что метоксигруппа при атоме С7 меняет свою ориентацию на противоположную по сравнению с ориентацией в молекуле гармина и его солях. Это происходит вследствие взаимного ван-дер-ваальсового отталкивания метокси- и формильной групп. В кристалле обнаружена слабая внутримолекулярная водородная связь между атомом $\mathrm{O} 2$ формильной группы и атомом водорода вторичной аминогруппы. Показано, что в кристалле молекулы образуют межмолекулярную водородную связь между теми же атомами (O2 и HN9A), в результате чего образуются димеры.
\end{abstract}

Ключевые слова: ЯМР-спектроскопия, масс-спектрометрия, рентгеноструктурный анализ, кристаллическая структура, водородная связь, гармин, 8-формилгармин, производное гармина.

\section{References}

1 Moloudizargari, M., Mikaili, P., Aghajanshakeri, S., Asghari, M.H., \& Shayegh, J. (2013). Pharmacological and Therapeutic effects of Peganum harmala and its main alkaloids. Pharmacognosy Rev., 7, 199-205.

2 Patel, K., Gadewar, M., Tripathi, R., Prasad, S.K., \& Patel, D.K. (2012). A review on medicinal importance, pharmacological activity and bioanalytical aspects of $\beta$-carboline alkaloid "Harmine". Asian Pac. J. Trop. Biomed., 2, 660-665.

3 Ishida, J., Wang, H.K., Bastow, K.F., Hu, C.Q., \& Lee, K.H. (1999). Antitumor Agents 201 Cytotoxicity of Harmine and $\beta$-Carboline Analogs. Bioorg. Med. Chem. Lett., 9, 3319-3324. 
4 Chen, D., Su, A., Fu, Y., Wang, X., Lu, X., \& Xu, W., et al. (2015). Harmine blocks herpes simplex virus infection through downregulating cellular NF-kappaB and MAPK pathways induced by oxidative stress. Antivir. Res., 123, 27-38.

5 Zhao, F., Gao, Z., Jiao, W., Chen, L., Chen, L., \& Yao, X. (2012). In vitro anti-inflammatory effects of $\beta$-carboline alkaloids, isolated from Picrasma quassioides, through inhibition of the iNOS pathway. Planta Med., 78, 1906-1911.

6 Sun, P., Zhang, S., Li, Y., \& Wang, L. (1997). Harmine mediated neuroprotection via evaluation of glutamate transporter 1 in a rat model of global cerebral ischemia. Neurosci. Lett., 583, 32-36.

7 Kim, H., Sablin, S.O., \& Ramsay, R.R. (1997). Inhibition of monoamine oxidase A by $\beta$-Carboline derivatives. Arch. Biochem. Biophys., 337, 137-142.

8 Cao, R., Fan, W., Guo, L., Ma, Q., Zhang, G., \& Li, J., et al. (2013). Synthesis and structure-activity relationships of asymmetric dimeric $\beta$-carboline derivatives as potential antitumor agents. Eur. J. Med. Chem., 60, 10-22.

9 Zhang, X.F., Sun, R., Jia, Y., Chen, Q., Tu, R.F., \& Li, K., et al. (2016). Synthesis and mechanisms of action of novel harmine derivatives as potential antitumor agents. Sci. Rep., 6, 33204-33209.

10 Nurmaganbetov, Zh.S., Shultz, E.E., Chernov, S.V., Turmukhambetov, A.Zh., Seydakhmetova, R.B., \& Shakirov, M.M., et al. (2011). Synthesis of substituted indolizino[8,7-b]indoles from harmine and their biological activity. Chem. Heterocycl. Comp., $46,1494-1499$.

11 Bruker (2015). SAINT. Bruker AXS Inc., Madison, Wisconsin, USA.

12 Bruker (2015). SADABS. Bruker AXS Inc., Madison, Wisconsin, USA.

13 Sheldrick, G.M. (2008). Crystal structure solution with SHELXS. Acta Crystaollogr. Sect. A., 64, 112-122.

14 Sheldrick, G.M. (2015). Crystal structure refinement with SHELXL. Acta Crystaollogr. Sect. C., 71, 3-8.

15 Allen, F.H., Kennard, O., Watson, D.G., Brammer, L., Orpen, A.G., \& Taylor, R. (1987). Tables of bond lengths deternined by X-ray and neutron diffraction. J. Chem. Soc. Perkin Trans., 2, 1-19.

16 Maulik, P.R., \& Basak, B.S. (1982). Harmine (7-methoxy-1-methyl-9H-pyrido[3,4-b]indole). Cryst. Struct. Commun., 11, 19-24.

17 Ferretti, V., Gilli, P., \& Borea, P.A. (2004). Structural features controlling the binding of beta-carbolines to the benzodiazepine receptor. Acta Crystallogr. Sect. B: Struct.Sci., 60, 481-489.

18 Turmukhambetov, A.Zh., Agedilova, M.T., Nurmaganbetov, Zh.S., Kazantsev, A.V., Adekenov, S.M., \& Shults, E.E., et al. (2009). Synthesis of quaternary salts of Peganum harmala alkaloids. Chem. Natur. Comp., 45, 601-603.

\section{Information about authors}

Turdybekov, Koblandy Muborykovich - Doctor of chemical sciences, Professor, Karagandy University of the name of academician E.A. Buketov, Karaganda, University street, 28, 100028, Kazakhstan; e-mail: xray-phyto@yandex.kz; https://orcid.org/0000-0001-9625-0060

Nurmaganbetov, Zhangeldy Seytovich - Candidate of chemical sciences, Assistant professor, Karaganda Medical University, Karaganda, Gogol street, 40, 100000, Kazakhstan; e-mail: nzhangeldy@yandex.ru; https://orcid.org/0000-0002-0978-5663.

Turdybekov, Dastan Muchtarovich - Candidate of chemical sciences, Head of the Department of Physics, Karaganda Technical University, Karaganda, N. Nazarbaev street, 56, 100010, Kazakhstan; e-mail: turdas@mail.ru, https://orcid.org/0000-0002-0245-0224.

Mukusheva, Gulim Kenesbekovna - Candidate of chemical sciences, Professor, Karagandy University of the name of academician E.A. Buketov, Karaganda, University street, 28, 100028, Kazakhstan; e-mail: mukusheva1977@list.ru; ID Scopus9243017000

Gatilov, Yurii Vasilevich - Doctor of chemical sciences, Leading researcher, N.N. Vorozhtsov Institute of Organic Chemistry of Siberian Branch of Russian Academy of Sciences, Novosibirsk, Lavrentiev Avenue, 9, 630090, Russia; e-mail: gatilov@nioch.ncs.ru; https://orcid.org/0000-0001-4365-0081. 